\title{
Community Health Agents: strategies and consequences of their network of relationships and interactions
}

\author{
Agente Comunitário de Saúde: estratégias e consequências da sua rede de relações e \\ interações
}

\section{Agente Comunitario de Salud: estrategias y consecuencias de su red de relaciones e interacciones}

Gabriela Marcellino de Melo Lanzoni ${ }^{1}$, Caroline Cechinel ${ }^{1}$, Betina Hörner Schlindwein Meirelles ${ }^{1}$

This study aimed to identify the strategies used by Community Health Agents on their relationships network and interactions to improve health care and its impact on a health center. The Grounded Theory was used as a methodological reference. Seventeen participants were interviewed between February and April 2009, among professionals and users of a health center in a city from southern Brazil. Freedom of communication, being the bond and promoting a connection between the community and the professionals were identified as strategies to strengthen the network of relationships and interactions of the Community Health Agents, creating as consequences good relationships between the staff and users and facilitating access to the health unit. One concludes that the Community Agent is a tool in the bond formation with significant potential to facilitate access to the services offered in Primary Health Care, starting from a complex web of relationships and interactions. Descriptors: Nursing; Family Health; Primary Health Care; Interpersonal Relations; Community Health Workers.

Este estudo objetivou identificar as estratégias utilizadas pelo Agente Comunitário em sua rede de relações e interações para melhoria da assistência à saúde e as suas repercussões em um centro de saúde. Utilizou-se a Teoria Fundamentada nos Dados como referencial metodológico. Foram entrevistados 17 participantes entre fevereiro e abril de 2009, dentre profissionais e usuários de um centro de saúde de um município ao sul do Brasil. Liberdade de comunicação, ser o elo e promover vínculo entre a comunidade e a equipe foram identificados como estratégias para o fortalecimento da rede de relações e interações do Agente Comunitário, gerando como consequências as boas relações na equipe - usuário e o favorecimento do acesso ao posto de saúde. Conclui-se que o Agente Comunitário é instrumento na formação de vínculo, com significativo potencial para facilitar o acesso aos serviços da Atenção Básica, a partir de uma teia complexa de relações e interações.

Descritores: Enfermagem; Saúde da Família; Atenção Primária à Saúde; Relações Interpessoais; Agentes Comunitários de Saúde.

El objetivo fue identificar las estrategias utilizadas por el Agente Comunitario em su red de relaciones e interacciones para mejorar la atención a la salud y su impacto en un centro de salud. Se utilizó la Teoría Fundamentada como referencia metodológica. Fueron entrevistados 17 participantes entre febrero y abril de 2009, entre profesionales y usuarios de un centro de salud al sur del Brasil. Libertad de comunicación, ser el enlace y promover vínculo entre la comunidad y el equipo fueron identificadas como estrategias para fortalecer la red de relaciones e interacciones de los Agentes Comunitarios, generando como consecuencias las buenas relaciones en el equipo-usuarios y fomento del acceso al centro de salud. En conclusión, el Agente Comunitario es fundamental en la formación de enlaces con gran potencial para facilitar el acceso a los servicios en la Atención Primaria, a partir de una compleja red de relaciones e interacciones.

Descriptores: Enfermería; Salud de la Familia; Atención Primaria de Salud; Relaciones Interpersonales; Agentes Comunitarios de Salud.

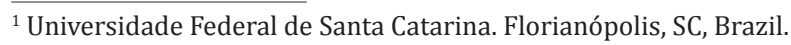




\section{Introduction}

The Primary Health Care (PHC) is one of the entrance gates for users in the public health system, being their favorite one, considering that through it strategies are deployed for patient compliance, strengthening of ties among the population and health teams, and consequent qualification of the community's health. It offers very diversified, unskilled and low technological density services ${ }^{(1-2)}$.

In order to restructure the logic of PHC, the Brazilian government created in 1994 based on the Community Agents Program (CAP), the Family Health Program (FHP), focusing mainly on the family unit, with full and continued assistance, which inserts the creation of a bond between the health team and the users assisted by it, defined by their place of residence previously delimited. The FHP was essential for the expansion and upgrading of PHC, prioritizing a model of counter-hegemonic attention. Moreover, the new proposed model goes beyond issues related to the health sector, focusing on all the factors that influence the population's health, such as education, safety, and sanitation ${ }^{(3)}$. To go beyond the assumptions of a program, the FHP was transformed into the Family Health Strategy (FHS).

In this scenario, the working process of a Community Health Agent (CHA) stands up and aims to strengthen the link between health professionals and the community. Residents of the coverage area of their responsibility, CHAs must know the community, identifying users who need more attention to health, as well as considering the fragility of the environment ${ }^{(4)}$.

For the development of health actions, the CHAs, having as a basic activity the conduction of home visits, guide the community about the health center's functioning, conduct activities and campaigns, and guide the community regarding the actions developed in different health services, having competence to engage with local leaders and in the discussion and solution of health problems and their social determinants present on their territory ${ }^{(5)}$.
In August 2013, out of the 5,570 Brazilian cities, 5,319 joined the FHE with the deployment of 34,216 family health teams, that is, coverage of $55.8 \%$ of the population. In parallel, 256,149 CHAs are present in 5,424 Brazilian cities, covering $64.4 \%$ of the population ${ }^{(6)}$. Although the integration of health teams and CHAs in the national context in increasing, one identifies an insufficient the interaction between the different professional categories ${ }^{(4)}$ with deviation of power flows to nurses or to the CHAs, which generates an inevitable leadership ${ }^{(7)}$.

Knowing that a network of well-structured relationships and interactions generates a dialogical and participatory relationship in health teams, reflecting on their actions with locals ${ }^{(4)}$, the question is: how do CHAs experience and give meaning to their relationships and interactions as members of a health team? What strategies are used by the CHAs in their network of relationships and interactions to improve health care? What are the main consequences of their actions? Thus, this study aimed to identify the strategies used by the CHAs in their network of relationships and interactions to improve health care and their impact on a health center in a city located south of the country.

\section{Method}

This is a qualitative study, which adopted as methodological framework the Grounded Theory (GT), developed by American sociologists who tried to build a theory based on data coming from the exploration of a phenomenon in the reality in which it is inserted, and the theoretical construct explains the action in the social context. The GT is a research method in which data collection, analysis and theory maintains a very close relationship, and it aims to identify, develop and relate concepts, being initiated in an area of extensive study, and allowing the theory to emerge influenced by the data discovered, and not only by researchers' speculations, being an important setting for action $^{(8)}$. 
Data collection took place from February to April 2009, at a health center in a city located south of the country, selected for being part of the urban area, having full health staff and interest in conducting this study.

Seventeen people participated in the study, divided into three sample groups, through individual, semi-structured interviews, in the institution or in the participants' residence. The first sample group was composed by the eight CHAs who worked at the health center. One used as the initial question: "How do you experience and give meaning to your relationships and interactions in the health team?". The sequence of questions was directed by the researchers, according to the interviewees' responses. From the data revealed, one realized the need to deepen the theme with the rest of the healthcare team, characterizing the second sample group, formed by two doctors, two nurses and a dentist, with whom were adopted the guiding questions: "How do you attend users/families?" and "How is your participation in collective actions in the health team and in the community?". Strengthening the previous categories and forming new ones, these data revealed the need for training of the third sample group, formed by four users of the health center, who were asked the guiding questions: "What meaning do you attribute to the CHAs' actions?" and "How do the CHAs' actions reflect in your care?" From this, the saturation data was reached, characterized by the repetition of data and absence of new relevant elements for analysis.

It is worth mentioning that in the GT data is collected and analyzed concurrently. Encoding is the central process of development of the theoretical model, occurring in three stages that happen simultaneously: open, axial, and selective coding. This provides the identification of search need of new subjects, as well as the creation of new sample groups, revealing the moment when the data saturation occurs. Open coding is the first step in the analysis, consisting of separating, examining, comparing and conceptualizing the data obtained, being the data analyzed line by line, and each sentence said by the respondent is converted into a code before being grouped by similarities and differences. The groupings of codes are the subcategories identified in accordance with the theme that they deal with. The second step of the analysis is the axial coding, in which the data are grouped again forming categories. Selective coding is the search and development of the phenomenon or central category, around which revolve all the other categories $^{(8)}$.

So, they are presented according to the paradigmatic model, ie, the categories are arranged in Causal Conditions, Intervening Conditions, Context, Strategies of Actions, Interaction and Consequences ${ }^{(8)}$.

From the analytical process, emerged the phenomenon "Analyzing the relationships and interactions of the Community Agent in order to improve health care as a complex network", supported by the categories: "Recognizing the community and health center as spaces for relationships and interactions", "Conceiving the quality of relationships between the staff and the community", "Valuing their work as CHAs", "Realizing nurses as mediators of relationship and interaction", "Being the link between the community and the staff" and "Favoring assistance through good relationships".

Recognizing the importance and relevance of the last two categories, linked to the components of the GT, strategies and consequences, one chose to present them and discuss them in detail because they have an intense inter-relationship of continuity, complementarity and dependence, demanding a deep and correlated look on each one of them.

It is emphasized that the research met the ethical aspects of Resolution 196/96 of the National Health Council ${ }^{(9)}$, being submitted and approved by the Ethics Committee for Research with Humans Beings from the Universidade Federal de Santa Catarina (CEP/UFSC) under protocol number 397/08. Aiming to ensure the anonymity of participants, pseudonyms were used for their designation, formed by the letter $\mathrm{G}$, as in sample group, followed by the number corresponding to 
the original group, associated with the letter I, as in interview, followed by the number that refers to the sequence in which the subject was interviewed.

\section{Results}

\section{Being a bond between the community and the staff}

"Promoting a bond between the staff and the community" was one of the strategies of action and interaction identified for creating a bond between the community and the staff. The data revealed the professionals' perception about the influence of the CHAs' performance to create a bond between the community and the health team. Thus, they show that the community's responsiveness suffers strong influence from the relationships network established by the CHAs with the population, as shown in the speech: I always tried to be well regarded in the community, at least until today I've never had problems being badly received in a visit or group activity. But if a health worker does not have a good relationship with his area, when I get to the house of the patient, therefore, I will no longer be well regarded (G2I12).

The health team considers the CHAs' work an important tool for approaching users and reveals that these are considered the best way to communicate with the community. The CHA, for being a resident of the area in which he works, is able to bring important information to the team, identifying particularities of the context in which users live, becoming essential for the performance of the entire FHS team, and helping professionals to understand factors that cause health problems to the population, as this testimony shows: One thing is a report from one of our team members, another thing is picking up the phone and asking. Not to mention that the information about living conditions, family background and all that stuff makes us understand some situations (G2I15).

To the creation of the bond mentioned, CHAs report that they use informal tools such as daily meetings and conversations with users, in order to be inserted in their lives and gain their trust in order to know all this population's problems. Starting from these strategies one identifies that this worker establishes a unique relationship with the user, being the only member of the healthcare team to have access to certain information, relevant to health maintenance. From the knowledge about the users' problems, the CHA identifies the need to inform the multidisciplinary team, and then facilitate contact with this individual who needs care, as shown by the speech: If they [users] want to tell a secret, we go to a place in the house or in the backyard, so that the person feels relaxed. There are things they do not tell in consultations and that they tell me. Then, I talk to them and try to convince them that it has to be reported to a doctor or to a nurse (G1I7).

The bond provided by the CHA of the healthcare team with the community is facilitated by the training of that worker to act with common problems of the population, being instructed to report any indications of noncompliance regarding the users' health to the other team members, generating a successful interdisciplinary approach, which allows the sum of knowledge and the connection of each member's work.

"Having the freedom to communicate" reveals the communication established by the CHA with the healthcare team and users as a strategy to create a bond between the community and the staff. The CHA reveals the freedom he has to ask certain things to the health care team, while he is also demanded by professionals, increasing the team's confidence in this worker. To accomplish this communication, the CHA does not need intermediaries, having autonomy to solve the obstacles of everyday life directly with each co-worker from the health team. Thus, communication with other professionals is used by the CHA to ensure the qualifications of the care provided, as shown in the speech: If I have to talk to the doctor, I don't have to go through the coordination first, then go to the nurse, and then finally talk to the doctor. I have this freedom, they gave me the freedom to come and ask: do you have a minute to have a word? (G1I4).

The monthly meetings of the healthcare team are perceived as an opportunity for communication between professionals, time to share ideas and experiences related to work. The participation of 
CHAs in multidisciplinary communication is made possible by the initiative of the other professionals that provide space for everyone to interact and communicate, allowing CHAs to have the autonomy to propose health actions and act in an integrated manner, as shown by the subject: ... in our team meetings we all have freedom to talk, we exchange a lot of information, I see that they perceive the respect of the team and they can speak, give their opinion and propose actions in health (G2I13).

Regarding the different profiles of professionals who work in the health team, the CHAs claim that they develop and implement different ways of getting closer and approaching to facilitate communication with each of the team members, so that they develop sensitivity in the identification of their co-workers personality, as well as the mood of each professional. These strategies make them choose the best time to approach professionals as well as identify best approaches.

Now with regard to the communication between CHAs and users, this happens respecting their particularities, such as schedules and places often preferred by the population, to establish a bond that provides the exchange of information relevant to health. Thus, the CHAs use tools to facilitate communication between the community and the health care team and are encouraged by health professionals of the multidisciplinary team to qualify this relationship, using communication as a strategy for closer ties between users and health staff.

\section{Favoring assistance through good relationships}

"Enabling access to the health unit" was one of the consequences identified to foster care through good relationships. The data revealed that the CHA is committed to educating the public about the actions performed by the health center according to the logic of PHC, guiding users to make use of the health service in order to enjoy it the best way, favoring thus, assistance, as shown in the following report: I said that our unit has good doctors. But even so she went to the Hospital... I explained that if the doctor has not indicated an expert yet, it is because he knows he can solve the problem. I reinforced that she should trust the doctor and wait (G113).

The CHAs' good relationships, besides covering the residents of the community, are also established with those working in the coverage area, being the focus of health promotion actions that CHAs participate, as recommended by the PHC. These people are questioned about the needs of health care, being attended at the health center when necessary, although not living in the coverage area, as shown by the speech: I visit some stores, many people do not live where they work, but I always ask if they need anything. They have no register file, but we have to attend them if it is a problem and we are able to help and treatment cannot be delayed (G1I1).

It is also clear that CHAs worry about sending users who require more specific health care to the health unit, to be attended by appropriate professionals according to the logic of attributions of professionals from the family health team. In some cases, the CHA is identified as the user's reference at the health center, being perceived as a reaching tool of health services by those who feel embarrassed to look for the unit, thus facilitating access of this portion of the population to the health center, as evidenced by one of the participants: Like those women who are sex professionals, some are embarrassed to go to the health unit, then they ask for condoms, they ask me (CHA) how to do gynecological exams before they do anything (G1I5).

Thus, the CHA allows the user to feel more familiar when inserted in the health service, for also being a member of the community and of the health care team. This favoring of assistance provided by the easy access to health centers that CHAs promote is recognized by everyone who is involved in the health service, professionals and users. It is shown, therefore, that the CHAs' good relationships generate qualified assistance.

"Linking the success of health initiatives to CHAs' relationships network" was one of the consequences related to the favoring of assistance through good relationships. It is perceived that 
through the good relationships established by the CHAs with the community there are effective actions that relate to the users' health, who are educated for health promotion and disease prevention, as shown by one of the participants: They treat me well, are polite, always receive what I say. ... They [mothers] let me do whatever I want, then they (children) go into the water in winter's cold. Little, scrawny, potbellied ones. They all received orientations and the infections stopped happening. Now, they come to the health unit, to thank me. They say: Oh, that big woman is great! (G1I2).

It is noticed that the good relations established by CHAs require that these professional endeavor to maintain contact with users, even when they do not want visits, but they show necessity of actions provided by these professionals, making the CHAs insist that the user accepts the worker's approach, which favors health actions.

Good relationships are established through a process that requires trust of users on the work of CHAs, which promotes greater inclusion of them in the individuals' lives, providing proximity to the issues, and enabling community approach to health care. Still, it was evident among respondents concern in maintaining harmonious relationships among members of the healthcare team, as they check its impact on the assistance provided.

Teamwork is viewed as a facilitator to advance in relation to the biomedical model, providing comprehensive care to individuals and the community, respecting the particularities of the work of each professional involved, adding their characteristics and forming a more comprehensive look, as brought by the report: While working together... there is a much larger scope than just treating a disease. And the involvement of the agents and the whole team enables a look at the community, look at patients as a whole in their psychological, family and social context to respond to their needs, because health is a very complex thing (G2I13).

The data reveal the user's perception about the establishment of good relationships by the CHAs, which provides support to the community, who feels assisted by competent professionals, which facilitates the effective maintenance of health through the intervention provided, as shown in the speech: Knowing that there is someone who cares about the patient as she does (CHA) and making herself available, giving her phone number if we need anything, makes her a very special person. As I told you, even if she is not living by my side, but having a person who knows the difficulties in taking care of my old mother, who has trouble walking, who has a heart disease seems to bring comfort... (G3I17).

Thus, through the confidence generated by CHAs to users and through these workers' commitment to establish close ties with the community, a favoring to assistance is created. Similarly, the CHAs' good relationship with professionals from the health team requires an interdisciplinary approach, with the effective participation of all the members. From this it is possible to notice an improvement in the care offered, creating the success of health actions through the relationships and interactions of the CHA's network.

\section{Discussion}

Understanding the CHA as a liaison between the community and the health service provides the worker a unique role within the team, taking him to effectively carry out his activities through actions in support of orientation, monitoring and health education, aiming mainly to promote the quality of life and well-being of the population ${ }^{(10)}$.

The CHA is as a strong mediator of patients' stress, for attending their numerous health demands. The requirement of being a resident of the coverage area he is responsible for, enables a permanent contact with the families, which facilitates the reorganization of health services, the work of surveillance and health promotion $^{(4,10)}$.

However, the fact that the CHAs are residents of the community do not guarantee them free access to homes during home visits, which could jeopardize public-private relationships and the freedom of these workers, as they have their private lives, habits and intimacy exposed. Moreover, this situation leads to greater physical and mental overload, since it becomes more difficult to dissociate the work from 
their personal lives ${ }^{(11)}$.

Still, it is noteworthy that building credibility has no direct relationship with the CHAs' place of residence, which may be a problem for the bond. The trust must be established through daily and permanently mutual contact(11-12).

In the analysis of the bond provided by CHAs between the community and the health service it was noticed that it is positive and effective in practice. In this sense, one highlights the use of CHAs as a tool for community outreach. This worker carries out the exchange relation of experience and knowledge between popular and scientific knowledge, providing the approach of health actions and the home context, increasing the population's power of resilience ${ }^{(4,13)}$. However, in another reality their performance is limited, because the biomedical model is still reproduced ${ }^{(5)}$, manifested by the CHAs' difficulties to talk about their health needs during team meetings.

The importance of CHAs' performance in the FHS context is recognized by these workers, which favors the development of bonds among users, because, when they are satisfied with their work, they can promote improvements in care. They consider themselves as partners of the population, and representatives of their claims against health services and intersectoral actions, and they take relevant information for the population, they feel gratified and valued to realize the acceptance of their guidelines by families ${ }^{(4,11)}$

However, when exposed to multiple relationships with professional and the community, CHAs experiences several events characterized by generating joys, such as the fact of helping people, solving problems and conducting active attitudes. Aspects related to sadness were identified due to structural and bureaucratic barriers to give support to users or to the health team, due to devaluation of their work, difficult have access to the team and consequently the lack of work organization/ management ${ }^{(14)}$. Still, faced with few opportunities to communicate or personal differences among members of the healthcare team, CHAs elaborate their own coping strategies, which curtails their involvement in the team work, and hinders the assistance provided by the staff ${ }^{(4,15)}$. Thus, the encouragement to freedom of communication stimulates the CHAs' relationships, which strengthens the bond with the healthcare team and, consequently, contributes to a good relationship with the community ${ }^{(15)}$.

In this same regard, encouraging CHAs' participation in the team's communication provides empowerment by increasing their responsibilities in the group's work, which generates in these workers a greater commitment, autonomy and initiative. It is pointed out that the regular meetings of the family health team, whose goal is to provide the planning and evaluation of health actions, may contribute to the integration of new employees, as well as facilitate the alignment of team members, fostering communication and knowledge exchange, strengthening the bond with the community ${ }^{(4)}$, as also observed in this study.

Through their power in the community mobilization, the CHAs can enable actions of health education and expand access to health services. It is imperative the need of the healthcare team to integrate the worker in the application and development of activities in the community, due to their closer understanding of the context ${ }^{(16)}$. As a highlight, the CHAs were inserted into the dynamic organization of oral health services, strengthening the social diagnosis of families and updating the users' registration, promoting increased access and increased number of people attended ${ }^{(17)}$.

However, the lack of integration of CHAs with the rest of the team generates demotivation of workers and undermines the quality of their actions in the community. The integration of the team provides the practice of interdisciplinary work, involving knowledge from many areas, popular and scientific, in order to promote and maintain the health of the population. Teamwork is recognized as a facilitator of the work process and is central to the care and guidance offered to users ${ }^{(13)}$. The 
individualization of responsibilities in the health team meets the assumptions of the FHS, which calls for shared responsibility by all the people involved. The achievement of effective team work, involving the various kinds of knowledge and practices, working together in the unit, at home and in the community allows the sharing of knowledge and information, and favors an integral and solving assistance ${ }^{(4)}$.

\section{Conclusion}

The CHA is a tool in the creation of bonds between the community and the health staff, with significant potential to facilitate access to the services offered in the PHC, from a complex web of relationships and interactions.

The categories: "Being the link between the community and staff" and "Favoring assistance through good relationships", which correspond to the component strategies and consequences of the phenomenon "Looking at the relationships and interactions of the Community Agent in improving health care, as a complex network", reveal meanings that interfere with the process of organization of health care, especially in the FHS.

Although this study has conducted the data collection in a single health unit, its findings can guide other FHS professionals to achieve successful health practices inspired by the strategies, and sharing the objectives achieved.

It is pointed out as a need for future research studies evaluating the accessibility of PHC services and its impact on users' and professionals' quality of life.

\section{Collaborations}

Lanzoni GMM and Meirelles BHS contributed to the creation, collection, analysis, interpretation of data, writing of the article and final approval of the version to be published. Cechinel C participated in the writing of the article and in the final approval of the version to be published.

\section{References}

1. Ministério da Saúde (BR). Política Nacional de Atenção Básica. Brasília: Ministério da Saúde; 2012.

2. Lavras C. Primary health care and the organization of regional health care networks in Brazil. Saúde Soc. 2011; 20(4):867-74.

3. Mota A, Schraiber LB. Primary Care in the Health System: debates from São Paulo in a historical perspective. Saúde Soc. 2011; 20(4):837-52.

4. Cardoso AS, Nascimento MC. Communication in the Family Health Program: the health agent as an integrating link between the team and the community. Ciênc Saúde Coletiva. 2010; 15(Supl 1):1509-20.

5. Santos LPGS, Fracolli LA. Community Health Aides: possibilities and limits to health promotion. Rev Esc Enferm USP. 2010; 44(1):76-83.

6. Ministério da Saúde (BR). Atenção básica. Saúde da família. Histórico da cobertura da saúde da família [Internet]. [citado 2013 set 19] Brasília: Ministério da Saúde; 2013 [cerca de 2 p]. Disponível em: http://dab.saude.gov.br/portaldab/historico_ cobertura_sf.php

7. Vicenzi RB, Girardi MW, Lucas ACS. Liderança em Saúde da Família: um olhar sob a perspectiva das relações de poder. Saúde Transform Soc 2010; 1(1):82-7.

8. Strauss A, Corbin J. Pesquisa qualitativa: técnicas e procedimentos para o desenvolvimento de teoria fundamentada. $2^{\mathrm{a}}$ ed. Porto Alegre: Artmed; 2008.

9. Ministério da Saúde (BR). Conselho Nacional de Saúde, Comissão Nacional de Ética em Pesquisa. Resolução №196 de 10 de outubro de 1996: aprova as diretrizes e normas regulamentadoras de pesquisa envolvendo seres humanos. Brasília: Ministério da Saúde; 1996.

10. Galavote HS, Prado TN, Maciel ELN, Lima RCD. Disclosing the work processes of the community health agents on the Family Health Strategy in Vitória (ES, Brazil). Ciênc Saúde Coletiva. 2011; 16(1):231-40.

11. Mascarenhas CHM, Prado FO, Fernandes MH. 
Factors associated with the quality of life of community health agents. Ciênc Saúde Coletiva. 2013; 18(5):1375-86.

12. Sant'Anna CF, Cezar-Vaz MR, Cardoso LS, Bonow CA, Silva MRS. Community: collective objective of nurses' work within the Family Health Strategy. Acta Paul Enferm 2011; 24(3):341-7.

13. Santos KT, Saliba NA, Moimaz SAS, Arcieri RM, Carvalho ML. Community Health Agent: status adapted with Family Health Program reality? Ciênc Saúde Coletiva 2011; 16(Supl 1):1023-28.

14. Galavote HS, Franco TB, Lima RCD, Belizario AM. Alegrias e tristezas no cotidiano de trabalho do agente comunitário de saúde: cenários de paixões e afetamentos. Interface. 2013; 17(46):575-86.
15. Peres CRFB, Caldas-Júnior AL, Silva RF, Marin MJS. The community health agent and working as a team: the easy and difficult aspects. Rev Esc Enferm USP. 2011; 45(4):905-11.

16. Nunes JM, Oliveira EN, Machado MFAS, Costa PNP, Vieira NFC. A participação de Agentes Comunitários de Saúde em grupo de educação em saúde. Rev Rene. 2012; 13(5):1084-91.

17. Coimbra MB, Annes FTM, Rodrigues PB, Vazquez FL, Pereira AC. Reorganização da demanda para atendimento odontológico no município de Amparo/SP: o desafio de garantir o acesso equânime às ações de saúde bucal. Odontol. 2011; 19(37):117-23. 